\title{
Women Dined Well: Bakhtinian Carnivalesque in Caryl Churchill's Top Girls
}

\author{
Dilayda Tülübaş, Humboldt University of Berlin
}

\begin{abstract}
"The human frame being what it is, heart, body and brain all mixed together, and not contained in separate compartments . . . a good dinner is of great importance to good talk. One cannot think well, love well, sleep well, if one has not dined well." -Virginia Woolf, A Room of One's Own (18)
\end{abstract}

The dinner scene in the first act of Caryl Churchill's post-WWII play Top Girls enables us to examine the individual subjectivities and collective consciousness of the iconic woman charac-ters. Churchill, by creating a dinner scene in the first act of her play, explores the inequalities faced by women across centuries and allows her characters to resist a system that creates certain types of gender identities. This essay highlights how the dinner scene and the increased appetite of woman characters at the dinner table in Top Girls function as a Bakhtinian "carnivalesque" that creates a topsy-turvy showing the reader the symbolic essence of food, the act of consump-tion, and their complex and dynamic relation with gender norms and identities.
Caryl Churchill's most celebrated play, Top Girls, begins with a remarkable dinner scene, where various women from history, literature and art come together to dine, celebrate, and share stories. Marlene, the play's central character, assumes the role of a party-giver, celebrating a recent promotion in the Top Girls Employment Agency with her friends. The dinner party consists of various women from fictional works or different time periods in history: Isabella Bird; a Victorian traveler, Lady Nijo; a thirteenth-century Japanese courtesan; Joan Gret, a ninth-century Pope; Dull Gret from Brueghel's painting; and Griselda, a fictional character from Geoffrey Chaucer's The Canterbury Tales. The dinner party creates a carnival sense of the world where

patriarchal structures and conventions are challenged through the end of the act. Such an impossible gathering of women in the first act of Top Girls makes it possible to explore the female experience, femininity, and their dynamic relation with food and festivity across centuries.

Through the dinner party, Churchill offers her characters an alternative life in which they are in a state of becoming. However, in a world turned upside down, these female characters are still haunted by the patriarchal system and male domination that culturally traumatized them. Churchill, who was heavily influenced by the social and political transformations of her decade, wrote Top Girls to critically examine the situation of women and their struggle to gain economic independence in post-war Britain. I argue that Russian literary critic and author Mikhail Bakhtin's theory of carnivalesque provides a conceptual vocabulary to explore and analyze the remarkable supper scene in Churchill's post-war play Top Girls. My aim in this essay is to illustrate how the dinner scene in the first act of the play functions 
as a "carnivalesque" that shows us the symbolic essence of food, the act of consumption and its complex and dynamic relation with gender norms and identities.

The carnivalesque, first described in Bakhtin's Rabelais and His World (1965), is a social institution where life is turned inside out and all sorts of eccentric behavior are accepted. Bakhtin, who saw carnivals of the Medieval and Renaissance period as being anarchic in nature, acknowledged that the carnival breaks apart rules and beliefs to make room for fresh and new beginnings. He describes the carnival sense of the world with five essences: "(1) it has a reversed life; (2) the participants have free and familiar contact; (3) it is replete with carnivalistic mésalliances; (4) it is infused with profanation; (5) it has crowning/decrowning acts; and (6) it parodies everything" (Yilmaz 51). By taking his inspiration from the folk festivals of Medieval and Renaissance cultures, Bakhtin conceptualizes a gateway to an egalitarian society since carnival and its suspension of hierarchical norms can make a "man renounce his official state as monk, cleric, scholar, and perceive the world in its laughing aspect" (Bakhtin 13).

The carnival as described by Bakhtin rejects the hierarchical structures and all sorts of inequalities. It is a topsy-turvy, utopian beginning that mocks the official systems and establishments and exposes the grotesque images of the body. In his Rabelais and His World, Bakhtin highlights the grotesque body and how it is not separated from the rest of the world:

It is not a closed, completed unit; it is unfinished, outgrows itself, transgresses its own limits. The stress is laid on those parts of the body that are open to the outside world, that is, the parts through which the world enters the body or emerges from it, or through which the body itself goes out to meet the world. This means that the emphasis is on the apertures or the convexities, or on various ramifications and offshoots: the open mouth, the genital organs, the breasts, the phallus, the potbelly, the nose. The body discloses its essence as a principle of growth which exceeds its own limits only in copulation, preg-nancy, child- birth, the throes of death, eating, drinking, or defecation. (Bakhtin 26)

Moreover, mouths in a carnival "are always open, eating and drinking, laughing, shouting: they take in and commune with the outer world and never shut it out, [which] corresponds to a cosmic openness" (Elliot 130). The open mouth as well as the act of consumption signifies the spirit of constant change and renewal. The collectivist spirit of the carnivalesque and popular banquets, according to Bakhtin, "shakes up the authoritative version of language and values, making room for a multiplicity of voices and meanings" (Elliot 130).

The trans-cultural and trans-historical nature of the dinner scene in Churchill's Top Girls presents us with challenging and complex questions about the class consciousness among women across centuries and their victimization caused by the system. Such an impossible gathering of women in a contemporary situation "constructs the present as just one of history's many time periods" that helps create a diversity of voices, which is particularly abundant in carnivalesque (Yi 43). Food in Top Girls functions both as a unifier and a divider that makes the experience of these women visible. Through their act of communal eating, these characters embark on a journey between the outer and the inner world. Theatre critic Kenneth Jones observes that Marlene in Top Girls creates a dinner party with people she does not 53 | Tülübaş 
even know, for she has no close friends of her own for the sake of rising in the job market, which is essentially led by her male counterparts (qtd. in Bastan 165). Furthermore, Sharon Ammen sees this scene in Top Girls as being initially utopic as five legendary figures show up to a contemporary woman's fantasy party to dine and celebrate (86). I argue that this gathering is a great example of Bakhtinian carnivalesque as it provides an alternative life, whereby women share their experiences of male domination and patriarchal authority accompanied by all sorts of food and drink. This gathering allows them to explore the exploitation of women across centuries, which produces certain types of gender identities. In fact, when the unnamed waitress makes an appearance with the wine bottle, Marlene and Nijo engage in a conversation that indicates the beginning of a Bakhtinian carnivalesque:

MARLENE: I think a drink while we wait for the others. I think a drink anyway. What a week.

The WAITRESS pours wine.

NIJO: It was always the men who used to get so drunk. I'd be one of the maidens, passing the sake. (Churchill 128)

As Margaret Visser puts it: "Food is never just something to eat" (qtd. in Jones 133). From identity to social status, food, and the way it is consumed is loaded with meanings. Therefore, it will be useful to focus on the food consumption of these characters at the dinner table as "food has a constant tendency to transform itself into situation" (Barthes 171). Moreover, "the communicative value of food lies in its appearance, preparation methods, eating habits, sensory perceptions, and eating contexts, which are all part of a system of differences in signification" (qtd. in Counihan and Van Esterik 24-25). As mentioned, the influence of patriarchal figures on the lives of these female characters dominates discussion throughout the party. While ordering her chicken and soup, Isabella recounts how she was so grieved when her father passed away. Similarly, Lady Nijo starts telling the guests about the death of her father while simultaneously ordering a Waldorf salad. Marlene, on the other hand, orders two rare steaks, lots of potatoes, and a few bottles of Italian white wine while casually listening to her guests (Churchill 134-135). In this instance, food works as a motif that highlights the different ways in which these female characters ingest and take nourishment. Marlene's choice of food, which in this scene is a "rare" steak "has been associated with strength, power, aggression, and sexuality" for decades. (qtd. in Jones 139). Unlike Isabella and Nijo, Marlene is portrayed as a hungry and demanding consumer; a character representative of her age. Churchill uses food in this scene as a highly effective motif to explore the gender roles that shape the experiences of women across centuries as the food preferences of these transcultural women heavily reflect complex cultural, social, and hierarchical structures that they had to abide by throughout their lives.

Having come from a working-class background, Marlene has achieved to find herself a place in the job market as a woman by internalizing and adapting to the patriarchal and capitalist norms of twentieth-century Britain. By throwing this dinner party, Marlene not only celebrates her promotion but also facilitates an opportunity for her fantasy female friends to create a new outlook 
through which they can connect with the outer world as never before. By constantly encouraging her guests to consume more food and drink more wine, Marlene seeks to regenerate a new order where everything is in a state of becoming. She achieves this as the carnival essence pro-liferates and characters get drunker. Lady Nijo's excitement upon being offered an alcoholic beverage for the first time in her life at the beginning of the supper party is an indicator of her social status at the Emperor's court (Churchill 128). In this carnivalesque, she is no longer a concubine that passes the sake for men. Instead, she is a woman who drinks as heavily as her male counterparts and enters into a realm of possibilities. This dinner offers Nijo the chance to leave her previous and only role as a concubine, experience life, evaluate her potential, and exist as herself without having to behave in compliance with the rules of patriarchal authority.

Isabella Bird, who is the first guest to arrive at Marlene's dinner party, mentions in turn to Nijo how she has tried the Japanese sake and how she has found it "fortifying after a day in the wet" (Churchill 128). Isabella is a Victorian-era world traveler who has lived an independent life engaging in male endeavors, unlike Lady Nijo. In the nineteenth century, a period in British history when women were seen merely as the "angel in the house," Isabella Bird traveled the world extensively and chose not to get married. Instead, she has tried the sake, had an adventurous life, and wrote a book. Her familiarity with and consumption of sake, which is considered as a highly masculine libation in Japan, indicates her masculine traits which contradicts the traditional portrayal of women of the Victorian era. In this era, many women "rejected meat associating a carnivorous diet with sexual precocity, abundant menstrual flow, and even nymphomania and insanity" (Andrievskik 142). Therefore, "denial of appetite expressed an ideal of female perfec-tion and moral superiority," something which Isabella lacks as she freely enjoys the food and drink at the dinner table (Andrievskik 142). Furthermore, one of the most remarkable characters at the dinner table, Pope Joan, gets drunker and recounts freely how she enjoyed her life as a man in Italy until it was revealed that she was a woman. She hid the fact that she is a woman for so long that she came to a point where she could not recognize her womanhood anymore and was alienated from her female body. In fact, she could not recognize that she was pregnant with one of her chamberlains until she had to give birth in the street during a religious procession. Only by disguising herself as a man and using her "male" privileges, she could achieve her goals and live a life full of freedom and comfort. The moment she stopped disguising her true gender, that is when she becomes a mother, she is stoned to death and murdered (Churchill 160).

The stage direction as Joan tells her story to the dinner guests carries a significance in the play. Churchill, by acknowledging that "the waitress brings more wine," aims to draw attention to the role of alcohol in removing the inhibitions and fears of the characters and en-couraging them to speak more frankly. As put by Gaston Bachelard, who focused on the significance of alcoholic unconsciousness in his works, alcohol "incorporates itself, so to speak, with that which is striving to express itself. It appears evident that alcohol is a creator of language. It enriches the vocabulary and frees the syntax" (qtd in Chimisso 206). Similarly, Marlene's dinner guests do not refrain from sharing the sensational and adventurous stories they have had as women living in different centuries as alcohol becomes a creator of language in the party:

55 | Tülübaş 
NIJO: What was he like, the chamberlain?

GRET: Big cock.

ISABELLA: Oh Gret.

MARLENE: Did he fancy you when he thought you were a fella?

NIJO: What was he like?

JOAN: He could keep a secret. (Churchill 154)

Marlene, by ordering more wine and encouraging her guests to drink more, aims at creating an untrammeled vision for the legendary guests, who according to Rebecca Cameron "remain locked in their own, singular perspectives" (qtd in in Cameron 156). On the one hand, drinking alcohol accelerates these women's desire to have a frank discussion and "makes accessible once again sources of pleasure which were under the weight of suppression" (qtd in Holowchak 85). On the other hand, their act of communal eating and increased appetite works as a tool that con-tributes to the creation of carnivalesque allowing the women to unite and create a resistance against patriarchy and established gender norms and etiquettes.

Dull Gret, who rarely speaks except for ordering more food, is also a remarkable character that Churchill has involved in this dinner party to highlight the sexist portrayal of women in sixteenth-century Europe. As painted in Bruegel's painting, Dull Gret, also known as Mad Meg, is a peasant woman, descending to hell while leading a troop of other peasant women. In this apocalyptic painting, Gret is seen wearing a military costume, armed with a sword gathering up cutlery. In the making of this painting, Bruegel is thought to have been inspired by a famous misogynistic Flemish proverb: "She could plunder in front of hell and return unscathed." Gret's occasional monosyllabic contributions to the conversation and her sudden and sharp remarks throughout the dinner such as "big cock" and "bastards" indicates her social position as a peas-ant woman. Unlike other women at the dinner table, Gret has little idea of how to communicate with others around her. Her silence makes it obvious that Gret is not used to an environment where she can have a voice of her own and express herself. She is mostly mute constantly asking for more bread and potatoes. Her constant appetite carries a significance throughout the play as "eating without constraint certainly repre-sents refusal to conform to socially determined gender behavior marked by moderation and constant worry about body image" (Andrievskikh 141). At the very end of the play, we learn that Gret's fight against devils in hell actually represents her vengeance against the Spanish ar-my, who murdered her children. By involving Gret at the dinner table, "Churchill endows [her] with a biography of oppression and a spirit of rebellion" (Cohn 115). Her lack of "feminine" manners and her constant appetite signify her stereotypically masculine characteristics-something she might have developed as a defense mechanism to fight her maternal instincts.

Food representations and "symbolism carries a particular importance for women due to the cul-turally determined association of women with cooking and nourishment" (Andrievskikh 137). Food and the dining scene in Top Girls, therefore, serves as a tool that helps us explore the female experience, femininity, and its constant and dynamic relation with food and festivity across centuries. The women at the dinner party, who are only connected to each other by their oppression under patriarchy, are offered by Churchill a transformative journey that ends with a moment of epiphany. Food in this work acts as a 
"system of language" that helps create a reversed life that challenges all social and patriarchal hierarchies that have previously traumatized the legendary characters (qtd in Counihan and Van Esterik 24). The stage direction through the end of the act shows us how the carnival essence in this act has proliferated as the communal eating and drinking of the characters contributed to the creation of carnivalesque, where the grotesque body "outgrows itself, transgresses its own lim-its" (Bakhtin 26):

NIJO is laughing and crying.

JOAN gets up and is sick in a corner.

MARLENE is drinking ISABELLA's brandy. (Churchill 182)

All of the women start reflecting on their past as a product of a system that oppresses women so much so that they do not realize they have a voice of their own. They enter a completely new stage of their life through this dinner that contributes to their sense of belonging and shared womanhood. Their performative manner at the dinner table as well as the kinds of food and drink they choose to consume gives us insight into the roles they take in order to create new social constructions that are stripped off all sorts of hierarchical rules.

Churchill utilizes food and the act of consumption to explore these characters' individual subjectivities and collective consciousness. By creating a carnival sense of the world through the dinner scene, Churchill proves the dominance of men in all sorts of social and trans cultural systems. The legendary characters' increased appetites work as a tool that contributes to the creation of carnivalesque allowing the women to unite and foment resistance to patriarchy and all sorts of established gender norms and etiquettes. In this carnivalesque, the women no longer restrict their appetites. Instead, they think well, dine well and challenge the rules of patriarchal establishment. Churchill ends the act with Isabella saying, "I knew my return of vigour was only temporary, but how marvellous while it lasted" (Churchill 183), which signifies "any temporary triumph of top girls, especially since Church-ill's characters have lapsed into laughing, crying, vomiting, stealing drinks" (Cohn 115). This temporary triumph as described by Cohn is achieved through the carnivalesque, which creates a diversity of voices as the women begin to challenge the patriarchal establishment and toast to their success and "extraordinary achievements":

ISABELLA: To Marlene.

MARLENE: And all of us.

JOAN: Marlene.

NIJO: Marlene.

GRET: Marlene.

MARLENE: We've all come a long way. To our courage and the way we changed our lives and our extraordinary achievements. They laugh and drink a toast.

(Churchill 182) 
Works Cited

Ammen, Sharon. "Feminist Vision and Audience Response: Tracing the Absent Utopia in Caryl Churchill's Top Girls." Utopian Studies, vol. 7, no. 1, 1996, pp. 86-102.

Andrievskikh, Natalia. "Food Symbolism, Sexuality, and Gender Identity in Fairy Tales and Modern Women's Bestsellers." Studies in Popular Culture, vol. 37, no. 1, 2014, pp. 137-153.

Bakhtin, Mikhail. Rabelais and His World. Translated by Hélène Iswolsky, Indiana University Press, 1984.

Barthes, Roland. Toward a Psychosociology of Contemporary Food Consumption in Food and Drink in History: Selections from the Annales Economies, Societies, Civilizations. ed. R. Forster and O. Ranum, trans. Elborg Forster and Patricia M. Ranum,. Baltimore, MD: Johns Hopkins University Press. 1979.

Bastan, Ajda. "The Memories of Women in Caryl Churchill's Top Girls". Turkish Studies, vol. 13, no. 20, 2018, pp. 165.

Cameron, Rebecca. "From Great Women to Top Girls: Pageants of Sisterhood in British Feminist Theater." Comparative Drama, vol. 43, no. 2, 2009, pp. 143-166.

Chimisso, Cristina. Gaston Bachelard: Critic of Science and the Imagination. Routledge, 2001.

Churchill, Caryl. Plays: 2 Softcops, Top Girls, Fen, Serious Money. Bloomsbury, 1990.

Cohn, Ruby. Anglo-American Interplay in Recent Drama. Cambridge University Press, 1995.

Counihan, Carole, et al. Food and Culture: A Reader. Routledge, 2013.

Elliot, Shanti. Carnival and Dialogue in Bakhtin's Poetics of Folklore. Folklore Forum. 1999.

Holowchak, Mark. Freud: From Individual Psychology to Group Psychology. The Rowman and Littlefield Publishing Group, 2012.

Jones, Michael Owen. "Food Choice, Symbolism, and Identity: Bread-and-Butter Issues for Folkloristics and Nutrition Studies (American Folklore Society Presidential Address, October 2005)." The Journal of American Folklore, vol. 120, no. 476, 2007, pp. 139.

Woolf, Virginia. A Room of One's Own and Three Guineas. 1957. Oxford University Press, 1992. 
Yilmaz, Victoria Bilge. Carnivalization of Gender Hierarchies in Virginia Woolf's Fiction. Diss. Middle East Technical University, 2016. Web. 08.09.2020.

Ying, Chris, ed. You and I Eat the Same: On the Countless Ways Food and Cooking Connect Us to One Another. Artisan, 2018. 